\title{
Nutrition, pharmacological and training strategies adopted by six bodybuilders: case report and critical review
}

Paulo Gentil (1), Claudio Andre Barbosa de Lira (1), Antonio Paoli (2), José Alexandre Barbosa dos Santos (3), Roberto Deivide Teixeira da Silva (3), José Romulo Pereira Junior (3), Edson Pereira da Silva (3), Rodrigo Ferro Magosso (4)

(1) College of Physical Education and Dance, Federal University of Goiás, Goiânia, Brazil; (2) Department of Biomedical Sciences, University of Padova, Padova, Italy; (3) ENAF Desenvolvimento Serviços Educacionais, Boa Vista, Brazil; (4) Post Graduation Program in Movement Sciences, UNESP - Universidade Estadual Paulista, Rio Claro, Brazil.

This article is distributed under the terms of the Creative Commons Attribution Noncommercial License (CC BY-NC 4.0) which permits any noncommercial use, distribution, and reproduction in any medium, provided the original author(s) and source are credited.

\begin{abstract}
The purpose of this study was to report and analyze the practices adopted by bodybuilders in light of scientific evidence and to propose evidence-based alternatives. Six (four male and two female) bodybuilders and their coaches were directly interviewed. According to the reports, the quantity of anabolic steroids used by the men was 500-750 mg/week during the bulking phase and 720-1160 mg during the cutting phase. The values for women were 400 and $740 \mathrm{mg}$, respectively. The participants also used ephedrine and hydrochlorothiazide during the cutting phase. Resistance training was designed to train each muscle once per week and all participants performed aerobic exercise in the fasted state in order to reduce body fat. During the bulking phase, bodybuilders ingested $\sim 2.5 \mathrm{~g}$ of protein $/ \mathrm{kg}$ of body weight. During the cutting phase, protein ingestion increased to $\sim 3 \mathrm{~g} / \mathrm{kg}$ and carbohydrate ingestion decreased by $10-20 \%$. During all phases, fat ingestion corresponded to $\sim 15 \%$ of the calories ingested. The supplements used were whey protein, chromium picolinate, omega 3 fatty acids, branched chain amino acids, poly-vitamins, glutamine and caffeine. The men also used creatine in the bulking phase. In general, the participants gained large amounts of fat-free mass during the bulking phase; however, much of that fat-free mass was lost during the cutting phase along with fat mass. Based on our analysis, we recommend an evidence-based approach by people involved in bodybuilding, with the adoption of a more balanced and less artificial diet. One important alert should be given for the combined use of anabolic steroids and stimulants, since both are independently associated with serious cardiovascular events. A special focus should be given to revisiting resistance training and avoiding fasted cardio in order to decrease the reliance on drugs and thus preserve bodybuilders' health and integrity.
\end{abstract}

Key Words: steroids, skeletal muscle hypertrophy, bodybuilding, resistance training

Bodybuilding differs from most sports because the participant's physique, rather than athletic performance, is judged. The ultimate goal of bodybuilders is to achieve a large muscle mass that is defined and symmetrical. Often their training periods are divided into bulking and cutting phases. The latter is emphasized in the weeks before the competition and is oriented for a decrease in body fat, while the first comprises the noncompetitive phase and is oriented for increasing muscle mass. To achieve their purposes, bodybuilders utilize a combination of resistance training, extreme diets, nutritional supplements and drugs. ${ }^{1-3}$. However, many of these strategies are based on common sense, rather than on scientific evidence, which may impose considerable health risks with no proven benefits. ${ }^{4}$ Many bodybuilding practices came to light due to reported cases of deaths, injuries and/or serious health problems occurring in bodybuilders. ${ }^{5-10}$ However, analysis of individual cases in clinical settings usually lacks important details. It is interesting to note that it has been reported that bodybuilders refuse to be treated and/or do not comply with medical recommendations, even in the presence of diagnosed health problems, ${ }^{5,6}$ probably because they are convinced that their current practices are vital for their success. However, many practices may not be necessary or can 


\section{Strategies adopted by six bodybuilders: a case report}

Eur J Transl Myol 27 (1): 51-66

be even counterproductive. Therefore, employing a critical view of these practices and proposing an evidence-based approach may help bodybuilders to preserve their health while still achieving the desired results. The purpose of this study is to report and analyze the practices adopted by six bodybuilders (two male Bodybuilders, two Men's Physique competitors and two women competing in the Wellness category) in the light of scientific evidence in order to offer a critical view and propose evidence-based alternatives for people involved or willing to be involved with bodybuilding.

\section{Material and Methods}

\section{Experimental procedures}

Since this is an observational study, the researchers were not responsible for the interventions. All data were provided by the participants and their coaches after the competition. Bodybuilders and their coaches were requested to describe in detail all their practices (training, diet, nutritional supplements and pharmacological agents). When any doubt arose, competitors/coaches were directly contacted to give further details. This procedure was facilitated by the fact that some authors of the present study were involved with bodybuilding, either as coaches or athletes.

\section{Participants}

All participants were amateur bodybuilders competing according to the standards of the International Federation of Bodybuilding and Fitness (IFBB). The participants were two male Bodybuilders in the same category (MB1 and MB2), two Men's Physique competitors belonging to the same category (MP1 and MP2) and two women competing in different Wellness categories (W1 and W2). MB1 was 26 years old, had 10 years of experience with resistance training and was in his second competition. The other participants were in their first competitions; MB2 was 28 years old and had 10 years of experience with resistance training; MP1 and MP2 had 22 and 19 years, respectively, and both had 2 years of experience with resistance training. W1 was 24 years old and had 4 years of experience with resistance training. W2 was 35 years old with 11 years of resistance training experience. All participants were among the best of their categories in the competition analyzed. MB1 won his category and was overall champion. MB2 was second place. W1 placed second in her category and W2 placed third. MP1 and MP2 were fifth and third, respectively. Participants were fully informed of the study aims and read and signed an informed consent form authorizing the use of their data. The study was approved by an Institutional Ethics Committee and conformed to the principles outlined in the Declaration of Helsinki.

Anthropometry and body composition

Body weight was determined with an electronic scale to the nearest $0.1 \mathrm{~kg}$ with subjects barefoot and wearing swim suits. Barefoot standing height was measured to the nearest $0.1 \mathrm{~cm}$ with a stadiometer. Participants were evaluated for body composition before and after the bulking and cutting phases. Body composition was assessed by an experienced examiner using a wholebody tetrapolar bioimpedance analyzer (Inbody230, Biospace, Seoul, Korea) with an eight-point tetrapolar electrode system. The participants were oriented to stand upright and to grasp the handles of the analyzer, thereby providing contact with eight electrodes (two for each foot and hand). Five segments (right and left arm, trunk, right and left leg) were independently analyzed using two different frequencies (20 and $100 \mathrm{kHz}$ ). The input variables included the patients' age, sex, height and actual body weight. The percentage body fat was computed through the proprietary algorithms, displayed on the analyzer's control panel and recorded.

All tests were performed in the morning ( $~ 8$ a.m.). Before anthropometric analysis, resting blood pressure was measured via auscultation by an experienced examiner after the participants had rested for 20 minutes in a sitting position. Heart rate was measured using a Polar A360 (Polar Electro Oy, Oulu, Finland).

\section{Results}

Participants were evaluated for body composition before and after the bulking and cutting phases. For each volunteer, the first date refers to the beginning of the bulking phase, the second date is the end of the bulking and beginning of the cutting phase and the third date represents the end of the cutting phase (Table 1). During the bulking phase, participants generally increased fatfree mass without altering fat mass, with the exception of MP2 whose fat-free mass did not change. The most notable increase was in W2, who showed a $20 \%$ increase in fat-free mass in only one month. All participants lost large amounts of body fat during the cutting phase, with a larger relative loss being achieved by MB2 and MP1 who dropped their body fat percentage by less than half during this period. However, during the cutting phase, all competitors besides MP1 lost fat-free mass, with the highest loss in MB1 and W1, who lost almost $10 \%$ of his fat-free mass. Their training routines are shown in Tables 2, 3 and, 4. The participants aimed to train each muscle group once a week with multiple sets of multi- and single-joint exercises performed to volitional fatigue. During the bulking phase, the male Bodybuilders and Wellness competitors performed sets of 8-12 repetitions with 2-3 minutes of rest between sets. During the cutting phase, the number of repetitions increased to $12-15$ and the rest intervals dropped to 45-60 seconds. The participants also increased the time spent in fasted cardio during the cutting phase. Men's Physique competitors trained with 8-15 repetitions and 50-70 seconds of rest during both the bulking and cutting phases. Regarding pharmacological agents, MB1 and MB2 used $500 \mathrm{mg} /$ week of testosterone enanthate, 200 
Strategies adopted by six bodybuilders: a case report

Eur J Transl Myol 27 (1): 51-66

\begin{tabular}{|c|c|c|c|c|c|c|c|c|}
\hline & $\begin{array}{l}\text { Date } \\
\text { (month- } \\
\text { day) }\end{array}$ & Height $(\mathrm{cm})$ & $\begin{array}{c}\text { Body } \\
\text { Weight (kg) }\end{array}$ & $\begin{array}{c}\text { Fat free } \\
\text { mass }(\mathrm{kg})\end{array}$ & $\begin{array}{c}\text { Body fat } \\
(\%)\end{array}$ & $\begin{array}{l}\text { Rest systolic } \\
\text { blood pressure } \\
(\mathrm{mmHg})\end{array}$ & $\begin{array}{l}\text { Rest diastolic } \\
\text { blood pressure } \\
(\mathrm{mmHg})\end{array}$ & $\begin{array}{l}\text { Rest heart } \\
\text { rate (bpm) }\end{array}$ \\
\hline \multirow{3}{*}{$\begin{array}{l}\text { Male } \\
\text { bodybuilder } 1\end{array}$} & $08-11$ & 168.1 & 82.1 & 65.9 & 19.7 & 140 & 75 & 80 \\
\hline & $09-30$ & & 89.3 & 73.7 & 17.5 & 116 & 62 & 76 \\
\hline & $11-14$ & & 72.6 & 66.8 & 8.0 & 123 & 79 & 81 \\
\hline \multirow{3}{*}{$\begin{array}{l}\text { Male } \\
\text { bodybuilder } 2\end{array}$} & $08-11$ & 171.5 & 87.4 & 71.7 & 18.0 & 141 & 83 & 70 \\
\hline & $09-30$ & & 92 & 73.4 & 20.2 & 165 & 81 & 59 \\
\hline & $11-14$ & & 75.5 & 69.5 & 7.9 & 111 & 81 & 102 \\
\hline \multirow[t]{3}{*}{ Wellness 1} & $08-11$ & 148.3 & 51.4 & 39.5 & 23.2 & 137 & 77 & 76 \\
\hline & $09-30$ & & 57.6 & 45.8 & 20.4 & 138 & 76 & 86 \\
\hline & $11-14$ & & 53.7 & 46.4 & 13.5 & 130 & 80 & 89 \\
\hline \multirow[t]{3}{*}{ Wellness 2} & $08-30$ & 169.1 & 63 & 48.2 & 23.4 & 126 & 69 & 86 \\
\hline & $09-30$ & & 71.5 & 58.0 & 18.9 & 132 & 77 & 74 \\
\hline & $11-14$ & & 65.2 & 55.0 & 15.7 & 133 & 79 & 82 \\
\hline \multirow{3}{*}{$\begin{array}{l}\text { Men's } \\
\text { Physique } 1\end{array}$} & $08-18$ & 190.0 & 94.3 & 80.5 & 14.6 & 136 & 72 & 74 \\
\hline & $09-26$ & & 99.9 & 87.7 & 12.2 & 136 & 65 & 84 \\
\hline & $11-14$ & & 92.2 & 87.6 & 5.0 & 120 & 72 & 62 \\
\hline \multirow{3}{*}{$\begin{array}{l}\text { Men's } \\
\text { Physique } 2\end{array}$} & $06-27$ & 180.5 & 90.6 & 81.3 & 10.2 & 151 & 81 & 82 \\
\hline & $08-21$ & & 89.8 & 81.2 & 9.6 & 166 & 75 & 82 \\
\hline & $11-14$ & & 81.5 & 76.6 & 6.0 & 124 & 82 & 104 \\
\hline
\end{tabular}

The first date is the beginning of the bulking phase, the second date is the end of the bulking and beginning of the cutting phase and the third date is the last measurement made before the competition in the end of the cutting phase.

$\mathrm{mg} /$ week of boldenone and $150 \mathrm{mg} /$ week of trenbolone acetate during the bulking phase. During the cutting phase, MB2 used $400 \mathrm{mg} /$ week of testosterone propionate, $200 \mathrm{mg} /$ week of stanozolol and 160 $\mathrm{mg} /$ week of oxandrolone during the cutting phase. MB1 used the same combination as MB2 during the cutting phase, but also added $400 \mathrm{mg} /$ week of drostanolone propionate. During the cutting phase there was also the introduction of ephedrine (15-45 $\mathrm{mg} /$ day) and hydrochlorothiazide (50-300 mg/day). Both MP1 and MP2 used $500 \mathrm{mg} /$ week of testosterone propionate during the bulking phase. During the cutting phase, they changed to $320 \mathrm{mg} /$ week of testosterone enanthate, 420 $\mathrm{mg} /$ week of oxandrolone, $250 \mathrm{mg} /$ day of caffeine, 15 $\mathrm{mg}$ /day of ephedrine and $120 \mathrm{mg} /$ day of theophylline. W1 and W2 used $200 \mathrm{mg} /$ week of stanozolol and 200 $\mathrm{mg} /$ week of nandrolone decanoate in the bulking phase and $200 \mathrm{mg} /$ week of stanozolol, $100 \mathrm{mg} /$ week of testosterone propionate, $140 \mathrm{mg} /$ week of oxandrolone and $300 \mathrm{mg} /$ week of drostanolone propionate during the cutting phase. They also added ephedrine (15-45 $\mathrm{mg} / \mathrm{day})$ and hydrochlorothiazide (50-300 mg/day) during the cutting phase. Nutritional supplements used in the bulking phase were whey protein concentrate, chromium picolinate, omega 3 fatty acids, branched chain amino acids (BCAA), vitamin C, poly-vitamins, glutamine and caffeine for both male Bodybuilders and Wellness participants. Male participants also ingested creatine monohydrate.

\section{Discussion}

This manuscript aimed to describe and analyze the practices adopted by six bodybuilders of both sexes in the light of scientific evidence. Data will be discussed separately for pharmacological agents, training, nutrition and supplements, as follows.

\section{Pharmacological agents}

MB1 and MB2 used $750 \mathrm{mg} /$ week of anabolic steroids during the bulking phase. During the cutting phase the amount increased to $760 \mathrm{mg} /$ week in MB2 and 1160 $\mathrm{mg} /$ week in MB1, which resulted in more than 105-165 $\mathrm{mg} /$ day. Considering that the normal testosterone production in men is $4-11 \mathrm{mg} / \mathrm{day},{ }^{11-14}$ the dosage is 9- 


\section{Strategies adopted by six bodybuilders: a case report}

Eur J Transl Myol 27 (1): 51-66

Table 2. Resistance training during the bulking and cutting phases of men bodybuilders competitors

\begin{tabular}{|c|c|c|c|c|c|}
\hline Monday & Tuesday & Wednesday & Thursday & Friday & Saturday \\
\hline \multicolumn{6}{|l|}{ Bulking } \\
\hline $\begin{array}{l}\text { Chest }(3 \text { exercises, } \\
\text { with } 10 \text { sets in } \\
\text { total, } 8-12 \text { reps and } \\
2-3 \quad \text { minutes } \\
\text { intervals between } \\
\text { sets) }\end{array}$ & $\begin{array}{l}\text { Back }(3 \text { exercises, } \\
\text { with } 10 \text { sets in } \\
\text { total, } 8-12 \text { reps and } \\
2-3 \quad \text { minutes } \\
\text { intervals between } \\
\text { sets) }\end{array}$ & $\begin{array}{l}45-60 \text { minutes of } \\
\text { cardio } \\
\text { (bicycle/treadmill) } \\
\text { at moderate } \\
\text { intensity in the } \\
\text { fasted state }\end{array}$ & $\begin{array}{l}\text { Quadriceps }(3 \\
\text { exercises, with } 10 \\
\text { sets in total, } 8-12 \\
\text { reps and } 2-3 \\
\text { minutes intervals } \\
\text { between sets) }\end{array}$ & $\begin{array}{l}\text { Biceps }(3 \text { exercises, } \\
\text { with } 10 \text { sets in } \\
\text { total, } 8-12 \text { reps and } \\
2-3 \quad \text { minutes } \\
\text { intervals between } \\
\text { sets) }\end{array}$ & $\begin{array}{l}45-60 \text { minutes of } \\
\text { cardio } \\
\text { (bicycle/treadmill) } \\
\text { at moderate } \\
\text { intensity in the } \\
\text { fasted state }\end{array}$ \\
\hline $\begin{array}{l}\text { Anterior and } \\
\text { middle deltoids ( } 3 \\
\text { exercises, with } 8 \\
\text { sets in total, } 8-12 \\
\text { reps and } 2-3 \\
\text { minutes intervals } \\
\text { between sets) }\end{array}$ & $\begin{array}{l}\text { Trapezius }(2 \\
\text { exercises, with } 6 \\
\text { sets in total, } 8-12 \\
\text { reps and } 2-3 \\
\text { minutes intervals } \\
\text { between sets) }\end{array}$ & $\begin{array}{l}\text { Abdominals }(1 \\
\text { exercise, with } 4 \text { sets } \\
\text { in total, 15-20 reps } \\
\text { and 2-3 minutes } \\
\text { intervals between } \\
\text { sets) }\end{array}$ & $\begin{array}{l}\text { Hamstrings }(2 \\
\text { exercises, with } 6 \\
\text { sets in total, } 8-12 \\
\text { reps and } 2-3 \\
\text { minutes intervals } \\
\text { between sets) }\end{array}$ & $\begin{array}{lr}\text { Triceps } & (3 \\
\text { exercises, with } 10 \\
\text { sets in total, } 8-12 \\
\text { reps and } 2-3 \\
\text { minutes intervals } \\
\text { between sets) }\end{array}$ & $\begin{array}{l}\text { Calves ( } 2 \text { exercises, } \\
\text { with } 7 \text { sets in total, } \\
15-20 \text { reps and } 2-3 \\
\text { minutes intervals } \\
\text { between sets) }\end{array}$ \\
\hline $\begin{array}{l}\text { Abdominals } \\
\text { exercise, with } 4 \text { sets } \\
\text { in total, 15-20 reps } \\
\text { and 2-3 minutes } \\
\text { intervals between } \\
\text { sets) } \\
\text { Cutting }\end{array}$ & $\begin{array}{l}\text { Posterior deltoids } \\
\text { ( } 1 \text { exercise, with } 4 \\
\text { sets in total, } 8-12 \\
\text { reps and } 2-3 \\
\text { minutes intervals } \\
\text { between sets) }\end{array}$ & & $\begin{array}{l}\text { Calves ( } 2 \text { exercises, } \\
\text { with } 7 \text { sets in total, } \\
15-20 \text { reps and } 2-3 \\
\text { minutes intervals } \\
\text { between sets) }\end{array}$ & $\begin{array}{l}\text { Abdominals } \\
\text { exercise, with } 4 \text { sets } \\
\text { in total, } 15-20 \text { reps } \\
\text { and 2-3 minutes } \\
\text { intervals between } \\
\text { sets) }\end{array}$ & \\
\hline $\begin{array}{l}\text { Back }(3 \text { exercises, } \\
\text { with } 10 \text { sets in } \\
\text { total, } 12-15 \text { reps } \\
\text { and } \\
\text { intervals between } \\
\text { sets) }\end{array}$ & $\begin{array}{l}\text { Chest }(4 \text { exercises, } \\
\text { with } 10 \text { sets in } \\
\text { total, } 12-15 \text { reps } \\
\text { and } \\
\text { intervals between } \\
\text { sets) }\end{array}$ & $\begin{array}{l}2 \text { hours of cardio in } \\
\text { the fasted state } \\
\text { Abdominals } \\
\text { exercise, with } 8 \text { sets } \\
\text { in total, } 15-20 \text { reps }\end{array}$ & $\begin{array}{l}\text { Quadriceps } \\
\text { exercises, with } 11 \\
\text { sets in total, 12-15 } \\
\text { reps and } 45- \\
60 \text { "intervals } \\
\text { between sets) }\end{array}$ & $\begin{array}{l}\text { Biceps (3 exercises, } \\
\text { with } 10 \text { sets in } \\
\text { total, } 8-12 \text { reps and } \\
45-60 " \text { intervals } \\
\text { between sets) }\end{array}$ & $\begin{array}{l}2 \text { hours of cardio in } \\
\text { the fasted state } \\
\text { Abdominals } \\
\text { exercise, with } 8 \text { sets } \\
\text { in total, } 15-20 \text { reps }\end{array}$ \\
\hline $\begin{array}{l}\text { Trapezius } \\
\text { exercises, with } 6 \\
\text { sets in total, 12-15 } \\
\text { reps and } 45-60 " \\
\text { intervals between } \\
\text { sets) }\end{array}$ & $\begin{array}{l}\text { Anterior and midle } \\
\text { deltoids } \\
\text { exercises, with } 9 \\
\text { sets in total, } 12-15 \\
\text { reps and } 45-60 " \\
\text { intervals between } \\
\text { sets) }\end{array}$ & $\begin{array}{l}\text { and } 45-60 " \text { intervals } \\
\text { between sets }\end{array}$ & $\begin{array}{l}\text { Hamstrings } \\
\text { exercises, with } 8 \\
\text { sets in total, 12-15 } \\
\text { reps and 45-60" } \\
\text { intervals between } \\
\text { sets) }\end{array}$ & $\begin{array}{l}\text { Triceps } \\
\text { exercises, with } 10 \\
\text { sets in total, 8-12 } \\
\text { reps and 45-60" } \\
\text { between sets) }\end{array}$ & $\begin{array}{l}\text { and } 45-60 " \text { intervals } \\
\text { between sets) } \\
\text { Calves ( } 2 \text { exercises, } \\
\text { with } 7 \text { sets in total, } \\
15-20 \text { reps and } 45- \\
60 " \text { intervals } \\
\text { between sets) }\end{array}$ \\
\hline $\begin{array}{l}\text { Posterior deltoids } \\
\text { ( } 2 \text { exercises, with } 6 \\
\text { sets in total, } 12-15 \\
\text { reps and } 45-60 " \\
\text { intervals between } \\
\text { sets) }\end{array}$ & $\begin{array}{l}\text { Calves ( } 2 \text { exercises, } \\
\text { with } 8 \text { sets in total, } \\
15-20 \text { reps and } 45- \\
60 " \text { intervals } \\
\text { between sets) }\end{array}$ & & $\begin{array}{l}\text { Hip adductors (1 } \\
\text { exercise, with } 4 \text { sets } \\
\text { in total, } 12-15 \text { reps } \\
\text { and } 45-60 " \\
\text { intervals between } \\
\text { sets) }\end{array}$ & & \\
\hline $\begin{array}{l}\text { Abdominals } \\
\text { exercise, with } 8 \text { sets } \\
\text { in total, } 15-20 \text { reps } \\
\text { and } 45-60 " \\
\text { intervals between } \\
\text { sets) }\end{array}$ & & & $\begin{array}{l}\text { Calves ( } 2 \text { exercises, } \\
\text { with } 8 \text { sets in total, } \\
15-20 \text { reps and } 45- \\
60 " \text { intervals } \\
\text { between sets) }\end{array}$ & & \\
\hline
\end{tabular}

41 times higher than the natural androgen production. Although MP1 and MP2 were taller and heavier, the amount of hormone used by them was lower than MB1 and MB2 during the bulking phase (500 mg/week), but increased to $720 \mathrm{mg} /$ week during the cutting phase. This is probably due to the characteristics of their categories, since Men's Physique requires a less muscular body than Bodybuilding. W1 and W2 used $400 \mathrm{mg} / \mathrm{week}$ of steroids during the bulking phase and $740 \mathrm{mg} /$ week during the cutting phase, resulting in 57 and 105 


\section{Strategies adopted by six bodybuilders: a case report}

Eur J Transl Myol 27 (1): 51-66

Table 3. Resistance training during the bulking and cutting phases of women wellness competitors

\begin{tabular}{|c|c|c|c|c|c|}
\hline Monday & Tuesday & Wednesday & Thursday & Friday & Saturday \\
\hline \multicolumn{6}{|l|}{ Bulking } \\
\hline $\begin{array}{l}\text { Abdominals } \quad(1 \\
\text { exercise, with } 4 \\
\text { sets, } 15-20 \text { reps and } \\
1-2 \quad \text { minutes } \\
\text { intervals between } \\
\text { sets) }\end{array}$ & $\begin{array}{l}\text { Chest ( } 2 \text { exercises, } \\
\text { with } 7 \text { sets in total, } \\
8-12 \text { reps and } 1-2 \\
\text { minutes intervals } \\
\text { between sets) }\end{array}$ & $\begin{array}{l}60 \text { minutes of cardio } \\
\text { (bicycle/treadmill) } \\
\text { at moderate } \\
\text { intensity in the } \\
\text { fasted state }\end{array}$ & $\begin{array}{l}\text { Hamstrings }(2 \\
\text { exercises, with } 6 \\
\text { sets in total, } 8-12 \\
\text { reps and 1-2 minute } \\
\text { intervals between } \\
\text { sets) }\end{array}$ & $\begin{array}{l}\text { Back ( } 2 \text { exercises, } \\
\text { with } 6 \text { sets in total, } \\
8-12 \text { reps and } 1-2 \\
\text { minute intervals } \\
\text { between sets) }\end{array}$ & $\begin{array}{l}60 \text { minutes of cardio } \\
\text { (bicycle/treadmill) } \\
\text { at moderate } \\
\text { intensity in the } \\
\text { fasted state }\end{array}$ \\
\hline $\begin{array}{l}\text { Quadriceps }(3 \\
\text { exercises, with } 10 \\
\text { sets in total, } 8-12 \\
\text { reps and } 1-2 \\
\text { minutes intervals } \\
\text { between sets) }\end{array}$ & $\begin{array}{l}\text { Anterior and midle } \\
\text { deltoids } \\
\text { exercises, with } 6 \\
\text { sets in total, } 8-12 \\
\text { reps and } 1-2 \\
\text { minutes intervals } \\
\text { between sets) }\end{array}$ & $\begin{array}{l}\text { Abdominals } \\
\text { exercise, with } 4 \text { sets } \\
\text { in total, } 15-20 \text { reps } \\
\text { and } 2-3 \text { minutes } \\
\text { intervals between } \\
\text { sets) }\end{array}$ & $\begin{array}{l}\text { Gluteus } \\
\text { exercises, with } 6 \\
\text { sets in total, } 8-12 \\
\text { reps and 1-2 minute } \\
\text { intervals between } \\
\text { sets) }\end{array}$ & $\begin{array}{l}\text { Trapezius } \\
\text { exercise, with } 3 \text { sets } \\
\text { in total, } 8-12 \text { reps } \\
\text { and } 1-2 \text { minute } \\
\text { intervals between } \\
\text { sets) }\end{array}$ & $\begin{array}{l}\text { Abdominals } \\
\text { exercise, with } 4 \text { sets } \\
\text { in total, } 15-20 \text { reps } \\
\text { and } 2-3 \text { minutes } \\
\text { intervals between } \\
\text { sets) }\end{array}$ \\
\hline $\begin{array}{l}\text { Hip adductors (1 } \\
\text { exercise, with } 3 \text { sets } \\
\text { in total, } 8-12 \text { reps } \\
\text { and } 1-2 \text { minutes } \\
\text { intervals between } \\
\text { sets) } \\
\text { Calves (1 exercise, } \\
\text { with } 4 \text { sets in total, } \\
8-12 \text { reps and } 1-2 \\
\text { minutes intervals } \\
\text { between sets) } \\
\text { Cutting }\end{array}$ & $\begin{array}{l}\text { Triceps }(2 \\
\text { exercises, with } 5 \\
\text { sets in total, } 8-12 \\
\text { reps and } 1-2 \\
\text { minutes intervals } \\
\text { between sets) }\end{array}$ & & $\begin{array}{l}\text { Calves ( } 2 \text { exercises, } \\
\text { with } 6 \text { sets in total, } \\
15-20 \text { reps and } 1-2 \\
\text { minute intervals } \\
\text { between sets) }\end{array}$ & $\begin{array}{l}\text { Biceps ( } 2 \text { exercises, } \\
\text { with } 6 \text { sets in total, } \\
8-12 \text { reps and } 1-2 \\
\text { minute intervals } \\
\text { between sets) } \\
\text { Abdominals } 1 \\
\text { exercise, with } 4 \text { sets } \\
\text { in total, } 15-20 \text { reps } \\
\text { and } 2-3 \text { minutes } \\
\text { intervals between } \\
\text { sets) }\end{array}$ & \\
\hline $\begin{array}{l}\text { Quadriceps } \\
\text { exercises, with } 12 \\
\text { sets in total, 12-15 } \\
\text { reps and } 45^{\prime \prime}-60 " \\
\text { intervals between } \\
\text { sets) }\end{array}$ & $\begin{array}{l}\text { Chest ( } 2 \text { exercises, } \\
\text { with } 7 \text { sets in total, } \\
12-15 \text { reps and } 45^{\prime-} \\
60 \text { " intervals } \\
\text { between sets) }\end{array}$ & $\begin{array}{l}2 \text { hours of cardio } \\
\text { (bicycle/treadmill) } \\
\text { at moderate } \\
\text { intensity in the } \\
\text { fasted state }\end{array}$ & $\begin{array}{l}\text { Gluteus } \\
\text { exercises, with } 6 \\
\text { sets in total, 12-15 } \\
\text { reps and } 45^{\prime \prime}-60 " \\
\text { intervals between } \\
\text { sets) }\end{array}$ & $\begin{array}{l}\text { Back ( } 2 \text { exercises, } \\
\text { with } 7 \text { sets in total, } \\
12-15 \text { reps and } 1-2 \\
\text { minute intervals } \\
\text { between sets) }\end{array}$ & $\begin{array}{l}2 \text { hours of cardio } \\
\text { (bicycle/treadmill) } \\
\text { at moderate } \\
\text { intensity in the } \\
\text { fasted state }\end{array}$ \\
\hline $\begin{array}{l}\text { Hip adductors ( } 1 \\
\text { exercise, with } 4 \text { sets } \\
\text { in total, } 12-15 \text { reps } \\
\text { and } 45^{\prime-}-60 " \\
\text { intervals between } \\
\text { sets) }\end{array}$ & $\begin{array}{l}\text { Anterior and } \\
\text { middle deltoids }(2 \\
\text { exercises, with } 6 \\
\text { sets in total, } 12-15 \\
\text { reps and } 45^{\prime \prime}-60 \text { " } \\
\text { intervals between } \\
\text { sets) }\end{array}$ & $\begin{array}{l}\text { Abdominals }(1 \\
\text { exercise, with } 8 \text { sets } \\
\text { in total, } 12-15 \text { reps } \\
\text { and } 45^{\prime \prime}-60 " \\
\text { intervals between } \\
\text { sets) }\end{array}$ & $\begin{array}{l}\text { Hamstrings } \\
\text { exercises, with } 6 \\
\text { sets in total, } 15-20 \\
\text { reps and } 45 "-60 " \\
\text { intervals between } \\
\text { sets) }\end{array}$ & $\begin{array}{l}\text { Trapezius } \\
\text { exercise, with } 3 \text { sets } \\
\text { in total, } 12-15 \text { reps } \\
\text { and } 1-2 \text { minute } \\
\text { intervals between } \\
\text { sets) }\end{array}$ & $\begin{array}{l}\text { Abdominals } \\
\text { exercise, with } 4 \text { sets } \\
\text { in total, } 15-20 \text { reps } \\
\text { and } 1-2 \text { minutes } \\
\text { intervals between } \\
\text { sets) }\end{array}$ \\
\hline $\begin{array}{l}\text { Calves ( } 1 \text { exercise, } \\
\text { with } 8 \text { sets in total, } \\
15-20 \text { reps and } 45 "- \\
60 \text { " intervals } \\
\text { between sets) }\end{array}$ & $\begin{array}{l}\text { Triceps }(2 \\
\text { exercises, with } 6 \\
\text { sets in total, 12-15 } \\
\text { reps and 45"-60" } \\
\text { between sets) }\end{array}$ & & $\begin{array}{l}\text { Calves ( } 2 \text { exercises, } \\
\text { with } 6 \text { sets in total, } \\
15-20 \text { reps and } 45^{\prime \prime} \\
60 \text { " intervals } \\
\text { between sets) }\end{array}$ & $\begin{array}{l}\text { Biceps ( } 2 \text { exercises, } \\
\text { with } 6 \text { sets in total, } \\
12-15 \text { reps and } 1-2 \\
\text { minute intervals } \\
\text { between sets) }\end{array}$ & \\
\hline $\begin{array}{l}\text { Abdominals } \\
\text { exercises, with } 8 \\
\text { sets in total, } 15-20 \\
\text { reps and } 45 "-60 " \\
\text { intervals between } \\
\text { sets) }\end{array}$ & & & & $\begin{array}{l}\text { Abdomen } \\
\text { exercises, with } 8 \\
\text { sets in total, 15-20 } \\
\text { reps and 1-2 minute } \\
\text { intervals between } \\
\text { sets) }\end{array}$ & \\
\hline
\end{tabular}

$\mathrm{mg} / \mathrm{day}$, respectively. Considering that women produce $0.2-0.4 \mathrm{mg}$ testosterone/day, ${ }^{11,12,14,15}$ the amount of androgen used was 142-285 and 264-528 times their natural androgen production during the bulking and cutting phases, respectively. The amount of androgen used by the studied bodybuilders in both phases was extremely high when compared with endogenous production. This high dosage has already been reported 


\title{
Strategies adopted by six bodybuilders: a case report
}

\author{
Eur J Transl Myol 27 (1): 51-66
}

Table 4. Resistance training during the bulking and cutting phases of men's physique competitors

\begin{tabular}{|c|c|c|c|c|c|}
\hline Monday & Tuesday & Wednesday & Thursday & Friday & Saturday \\
\hline \multicolumn{6}{|l|}{ Bulking } \\
\hline $\begin{array}{l}\text { Chest ( } 3 \text { exercises, } \\
\text { with } 9 \text { sets in total, } \\
8-15 \text { reps and } 50 "- \\
70^{\prime} \text { intervals } \\
\text { between sets) }\end{array}$ & $\begin{array}{l}\text { Quadriceps } \\
\text { exercises, with } 9 \\
\text { sets in total, } 8-15 \\
\text { reps and } 50 "-70^{\prime} \\
\text { intervals between } \\
\text { sets) }\end{array}$ & $\begin{array}{l}\text { Back (3 exercises, } \\
\text { with } 9 \text { sets in total, } \\
8-15 \text { reps and } 50 "- \\
70 \text { ' intervals } \\
\text { between sets) }\end{array}$ & Rest & $\begin{array}{l}\text { Biceps ( } 2 \text { exercises, } \\
\text { with } 6 \text { sets in total, } \\
8-15 \text { reps and } 50 "- \\
70^{\prime} \text { intervals } \\
\text { between sets) }\end{array}$ & $\begin{array}{l}\text { Quadriceps } \\
\text { exercises, with } 9 \\
\text { sets in total, } 8-15 \\
\text { reps and } 50 "-70^{\prime} \\
\text { intervals between } \\
\text { sets) }\end{array}$ \\
\hline $\begin{array}{l}\text { Anterior and medial } \\
\text { deltoids } \\
\text { exercises, with } 4 \\
\text { sets in total, } 8-15 \\
\text { reps and } 50^{\prime \prime}-70^{\prime} \\
\text { intervals between } \\
\text { sets) }\end{array}$ & 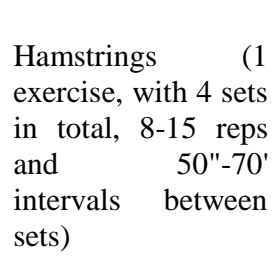 & 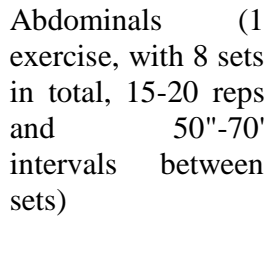 & & $\begin{array}{l}\text { Triceps } \\
\text { exercises, with } 6 \\
\text { sets in total, } 8-15 \\
\text { reps and } 50^{\prime \prime}-70^{\prime} \\
\text { intervals between } \\
\text { sets) }\end{array}$ & $\begin{array}{l}\text { Hamstrings } \\
\text { exercise, with } 4 \text { sets } \\
\text { in total, } 8-15 \text { reps } \\
\text { and } 50 "-70 \\
\text { intervals between } \\
\text { sets) }\end{array}$ \\
\hline $\begin{array}{l}\text { Calves ( } 1 \text { exercise, } \\
\text { with } 4 \text { sets in total, } \\
8-15 \text { reps and } 50 "- \\
70^{\prime} \quad \text { intervals } \\
\text { between sets) }\end{array}$ & & & & $\begin{array}{l}\text { Calves ( } 1 \text { exercise, } \\
\text { with } 4 \text { sets in total, } \\
8-15 \text { reps and } 50 "- \\
70^{\prime} \text { intervals } \\
\text { between sets) }\end{array}$ & \\
\hline 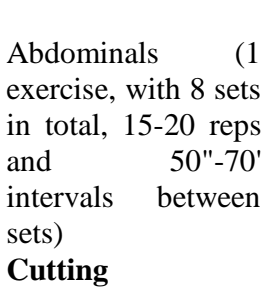 & & & & 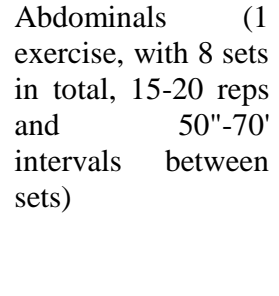 & \\
\hline $\begin{array}{l}\text { Chest ( } 3 \text { exercises, } \\
\text { with } 9 \text { sets in total, } \\
8-15 \text { reps and } 50 "- \\
70 \text { ' intervals } \\
\text { between sets) }\end{array}$ & $\begin{array}{l}\text { Quadriceps } 3 \\
\text { exercises, with } 9 \\
\text { sets in total, } 8-15 \\
\text { reps and } 50 "-70^{\prime} \\
\text { intervals between } \\
\text { sets) }\end{array}$ & $\begin{array}{l}\text { Back ( } 3 \text { exercises, } \\
\text { with } 9 \text { sets in total, } \\
8-15 \text { reps and } 50 "- \\
70^{\prime} \text { intervals } \\
\text { between sets) }\end{array}$ & Rest & $\begin{array}{l}\text { Biceps ( } 2 \text { exercises, } \\
\text { with } 6 \text { sets in total, } \\
8-15 \text { reps and } 50 "- \\
70^{\prime} \text { intervals } \\
\text { between sets) }\end{array}$ & $\begin{array}{l}\text { Quadriceps } 3 \\
\text { exercises, with } 9 \\
\text { sets in total, } 8-15 \\
\text { reps and } 50 "-70^{\prime} \\
\text { intervals between } \\
\text { sets) }\end{array}$ \\
\hline $\begin{array}{l}\text { Anterior and medial } \\
\text { deltoids } \\
\text { exercises, with } 4 \\
\text { sets in total, } 8-15 \\
\text { reps and } 50 "-70^{\prime} \\
\text { intervals between } \\
\text { sets) }\end{array}$ & $\begin{array}{l}\text { Hamstrings } \\
\text { exercise, with } 4 \text { sets } \\
\text { in total, } 8-15 \text { reps } \\
\text { and } 50^{\prime \prime}-70^{\prime} \\
\text { intervals between } \\
\text { sets) }\end{array}$ & 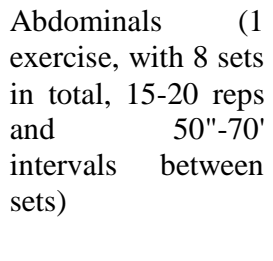 & & $\begin{array}{l}\text { Triceps }(2 \\
\text { exercises, with } 6 \\
\text { sets in total, } 8-15 \\
\text { reps and } 50^{\prime \prime}-70^{\prime} \\
\text { intervals between } \\
\text { sets) }\end{array}$ & $\begin{array}{l}\text { Hamstrings } \\
\text { exercise, with } 4 \text { sets } \\
\text { in total, } 8-15 \text { reps } \\
\text { and } 50 "-70 \\
\text { intervals between } \\
\text { sets) }\end{array}$ \\
\hline $\begin{array}{l}\text { Calves ( } 1 \text { exercise, } \\
\text { with } 4 \text { sets in total, } \\
8-15 \text { reps and } 50 "- \\
70^{\prime} \quad \text { intervals } \\
\text { between sets) }\end{array}$ & & & & $\begin{array}{l}\text { Calves (1 exercise, } \\
\text { with } 4 \text { sets in total, } \\
8-15 \text { reps and } 50 "- \\
70^{\prime} \text { intervals } \\
\text { between sets) }\end{array}$ & \\
\hline $\begin{array}{lr}\text { Abdominals } & (1 \\
\text { exercise, with } 8 \text { sets } \\
\text { in total, } & 15-20 \text { reps } \\
\text { and } & 50 "-70^{\prime} \\
\text { intervals } & \text { between } \\
\text { sets) }\end{array}$ & & & & 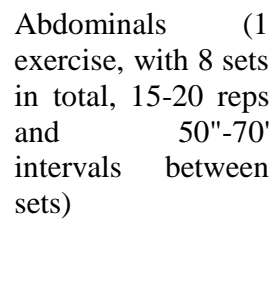 & \\
\hline
\end{tabular}

in the literature. ${ }^{16}$ The hormone dosage during the cutting phase increased in all competitors, except for MB2. This might be related to the alleged effects of testosterone in promoting fat $\operatorname{loss}^{17-19}$ and also to counteract muscle catabolism that usually accompanies extreme fat loss strategies. However, this strategy did 
not seem to be effective, since most of the participants, lost fat-free mass during the cutting phase, which is in accordance with other studies that also demonstrated that use of anabolic steroids was not able to generate positive changes in body composition. ${ }^{20,21}$ The participants also changed the type of anabolic steroid used from the bulking to cutting phases. In the bulking phase, the participants commonly used testosterone enanthate, boldenone, nandrolone undecanoate and trenbolone. In the cutting phase, the drugs of choice were propionate, stanozolol, propionate drostanolone and oxandrolone. However, there was an exception for the Men's Physique participants who used testosterone propionate during the bulking phase and enanthate during the cutting phase. Indeed, it has been demonstrated that athletes typically use anabolic steroids in a "stacking" regimen, which means the use of different drugs simultaneously in order to increase the potency of each drug. ${ }^{22}$ Drug choice was based on the belief that some drugs would result in greater fat loss than others. However, this practice is not supported by the literature. Previous studies have shown that endogenous testosterone per se may be associated with fat loss. ${ }^{17,18}$ However, some studies reported no reduction in body fat with anabolic steroid use ${ }^{20,21}$ while others reported reductions in body fat in healthy people $\mathrm{e}^{19,23,24}$, the obese ${ }^{25}$ and clinical settings, ${ }^{26-28}$ irrespective of the drugs used. If we consider that testosterone acts in the adipose tissue through androgen receptors, ${ }^{29-31}$ it is not plausible to believe that different drugs would result in different effects in body fat or muscle accretion, since they will act on the same receptor. ${ }^{30}$ Additionally, the use of large amounts of anabolic steroids may increase its conversion to estrogen, which may have a negative impact on fat loss. Although recent studies reported that testosterone aromatization may not influence body composition at therapeutic doses, ${ }^{32}$ its effects at higher doses are unkonwn. The effects of androgens on the cardiovascular system are widely studied and recognized. Briefly, misuse of androgens can cause myocardial infarctions, alterations in serum lipids (decreased HDL and increased LDL), elevation in blood pressure and increased risk of thrombosis (for review see Hoffman et $a^{22}{ }^{22}$ ). In the present study, all participants showed resting systolic blood pressure values higher than optimal in at least one of the three measurements performed. MB1, MB2 and MP2 showed blood pressure values that characterized hypertension at some time. ${ }^{33}$ Although blood exams were not available, all participants reported that their HDL values were suboptimal in previous exams. It is important to stress that both higher blood pressure and low HDL are associated with cardiovascular events caused by anabolic steroids. ${ }^{34}$ Even though no participant had reported any serious cardiovascular events in the past, these altered values could expose them to an increased risk. Moreover, the literature provides many cases of serious cardiovascular events associated with anabolic steroid abuse in bodybuilders. ${ }^{6,35-37}$ The increased cardiovascular risk associated with steroid use seems to be undeniable. ${ }^{6,38}$ Additionally, many studies confirm that the abuse of anabolic substances produces profound and partly irreversible changes in various organs and systems, and that these changes tend to be related to the type, duration and amount of anabolic steroids used. The effects of major concern are those on the liver, cardiovascular and reproductive systems, and on the psychological status of anabolic-androgenic steroid users. ${ }^{20,39-42}$ Certainly not all effects occur in all persons, nor are the effects necessarily obvious. ${ }^{22}$ In addition to dosage, one must consider the duration of use to arrive at a total exposure. In this sense, the use in bodybuilding seems to be particularly alarming since it combines large doses and long periods of use. ${ }^{38,42}$ Although it is recommended to not exaggerate the medical risks associated with anabolic steroids, ${ }^{22}$ it is important to emphasize that an attitude of personal invulnerability to their adverse effects is certainly misguided. ${ }^{41}$ Bodybuilders usually rely on individual cases of steroid users that did not develop health problems to suggest that steroid use may be safe; however, one must know the difference between increased risk and certainty of the occurrence of an event. The use of ephedrine and diuretics in the cutting phase may also impose an imminent risk to the bodybuilders' health. Ephedrine misuse has been associated with serious cardiovascular events $^{43,44}$ and diuretics have been anecdotally associated with the death of some bodybuilders and their misuse is associated with health problems. ${ }^{45,46}$ Dehydration could have a negative impact on muscle metabolism without positively affecting fat metabolism, since there seems to be a close relationship between cellular hydration and nitrogen balance. ${ }^{47}$ In addition, previous studies have reported that hypo-osmolality is associated with increased lipolysis and decreased protein breakdown. ${ }^{48,49}$ Therefore, diuretic use may not be only hazardous to the bodybuilders' health, but also counterproductive to their objectives.

\section{Training}

Resistance training

All participants split training sessions in order to train each muscle group every week. Although a recent review suggests that a higher training frequency may result in higher muscle hypertrophy, ${ }^{50}$ there are studies in which trained participants obtained significant results with this type of routine. ${ }^{51}$ Moreover, Ahtiainen et al. ${ }^{52}$ reported that trained men were only able to repeat a training session 6-7 days after performing nine sets of lower body exercise. Therefore, training one muscle group every week seems to be supported by the current literature. One criticism regarding the splitting routine involves exercise choice, since it did not consider that shoulder and upper limb muscles are highly involved in multi-joint upper body exercise. ${ }^{53-56}$ Additionally, 


\section{Strategies adopted by six bodybuilders: a case report}

Eur J Transl Myol 27 (1): 51-66

previous studies have shown that gains in elbow flexor muscle size and strength were similar for subjects that performed elbow flexions or lat pull-downs. ${ }^{57}$ Moreover, other studies showed that the addition of single-joint exercises did not increase the gains in muscle size and strength in untrained ${ }^{58}$ or trained subjects. ${ }^{59}$ A counterpoint to this argument can be made with the study of Soares et al. ${ }^{60}$ in which upper limb muscles recovered faster after seated rows than during isolated elbow flexions. Probably, the difference may be related to the exercise used, since the ratio of activation of latissimus dorsi to biceps during seated rows is higher than during lat pull-downs, ${ }^{61}$ which could have led to lower elbow flexor damage in the study of Soares et al. ${ }^{60}$ Considering that testosterone increases muscle recovery, ${ }^{62}$ protein synthesis ${ }^{63}$ and satellite cell activity, ${ }^{64,} 65$ the accretion of isolated exercises would have difficulty in inducing a state of overtraining in bodybuilders using anabolic steroids. However, testosterone may impair tendon adaptation to resistance training $^{66}$ and anabolic steroids users showed a markedly increased risk of tendon ruptures, particularly in the upper-body. ${ }^{67}$ This is particularly interesting, because upper body tendon rupture are not common among people that do not have a history of anabolic steroid use. In a cross-sectional cohort study, Kanayama et al.67 reported that the hazard ratio for a first ruptured tendon in anabolic steroid users versus nonusers was 9.0 , and upper body tendon ruptures occurred in $17 \%$ of the anabolic steroid users, while none occurred in nonusers. The unnecessary and excessive use of isolated exercises may cause excessive strain in upper body tendons, thus aggravating the problem. The empirical evidence is that all participants of our study had a history of joint pains and one participant had a severe shoulder injury prior to the preparation period. Therefore, considering that isolated exercises bring little, if any, benefit for muscle size and strength and that upper body tendons are particularly vulnerable in anabolic steroid users, it would be advisable to decrease the volume of upper body isolated exercise. During the cutting phase, male Bodybuilder and Wellness competitors increased the number of repetitions performed and decreased the time intervals between sets. Men's Physique participants kept their training routines with high repetitions and short rest intervals between sets during the whole period, since their purpose was not to promote large increases in muscle mass. Although the use of high repetition and low workloads for acquiring muscle definition is a common practice, 3 previous studies have shown that exercises performed with a lower number of repetitions and higher workloads are more efficient than high repetition, high volume training in elevating metabolism ${ }^{68}$ and promoting fat loss ${ }^{69,70}$ Additionally, considering that low carbohydrate ingestion during the cutting phase may compromise exercise performance, ${ }^{71}$ using low repetition with high load and long rest intervals during this phase may be advantageous, since this type of training rely less on the glycolytic system. ${ }^{72,73}$ We noted with caution the use of isolated knee adductions for women. According to the participants, the exercise was included to induce specific hypertrophy of the hip adductors and modify the shape of the thighs. Although there is evidence that a training program composed only of leg press and knee extension promotes significant hypertrophy of the hip adductors, ${ }^{74}$ the use of isolated exercises may be granted if there is a need to bring specific adaptations for this muscle group. However, it is important to note that women are more prone to develop patellofemoral problems than men and this incidence may be related to weakness of the posterolateral complex. ${ }^{75,76}$ Therefore, the use of isolated knee adductions may create an imbalance in the hip joint and increase the probability of developing knee injuries. Therefore, our suggestion is to avoid isolated hip adduction or, if it is necessary for aesthetical reasons, it is recommended to introduce exercises for hip abductors and external hip rotators to prevent patellofemoral problems, as previously used in the studies of Fukuda et al. ${ }^{77,78}$

\section{Aerobic training}

Male Bodybuilders and Wellness competitors performed 45-60 minutes of aerobic exercise in the fasted state 2 days per week in the bulking phase. In the cutting phase weekly frequency was kept constant but the duration of each session increased to 2 hours. Men's Physique competitors did not perform aerobic exercise in the bulking phase, but added 40 minutes of fasted aerobic exercise in the cutting phase. Although the participants reported that performing exercise in the fasted stated is a common practice among bodybuilders, a previous study showed that it brings no benefit in terms of fat $\operatorname{loss}^{79}$ and can even negatively impact energy expenditure and fat metabolism. ${ }^{80}$ Probably, this negative effect on metabolism was offset by the use of large doses of ephedrine and caffeine, which have been shown to increase metabolism and fat oxidation. ${ }^{81,82}$ Based on the current body of scientific evidence, it is highly advisable to discourage the performance of fasted aerobic exercise in order to prevent negative alterations in metabolism and reduce the need for thermogenic ingestion. Thus, the participants could have equivalent results while decreasing the amount of drugs used. Additionally, the performance of high volumes of aerobic exercise has a negative impact on muscle hypertrophy. ${ }^{83}$ The loss of fat-free mass even with an increase in anabolic steroid use during the cutting phase may be evidence for that phenomenon. Considering that the higher the exercise intensity, the higher the fat $\operatorname{loss}^{83,84}$ and that some studies suggest that the effect of regular low-intensity aerobic exercise on body fat is negligible, ${ }^{85}$ it would be recommended to reduce the volume of aerobic exercise and increase its intensity. Another strategy to prevent muscle loss would be to 


\section{Strategies adopted by six bodybuilders: a case report}

Eur J Transl Myol 27 (1): 51-66

prefer cycling to running, since the latter may have a more negative interaction with resistance training ${ }^{83,85}$ Taken together, high intensity interval training on the cycle ergometer would be preferable to long duration and low-intensity running for both losing fat and preserving fat-free mass.

\section{Nutrition}

Unfortunately, it was not possible to retrieve detailed nutritional plans because the participants' diets constantly changed according to their perceptions; i.e. carbohydrate ingestion increased if they felt that they were losing too much fat-free mass and decreased in order to reduce body fat. In general, their bulking diets were hypercaloric, high protein $(2.5 \mathrm{~g}$ of protein per $\mathrm{kg}$ of body mass, with each meal containing 0.33 to $0.55 \mathrm{~g}$ of protein per $\mathrm{kg}$ of body weight) and low fat ( $15 \%$ of calories coming from fat). The major sources of carbohydrate were rice, potatoes, bread and oatmeal. Dietary protein usually came from chicken, lean red meat, egg whites and whey protein concentrate. As competition approached, the competitors increased their protein ingestion to $\sim 3 \mathrm{~g} / \mathrm{kg}$ of body weight and decreased carbohydrate ingestion by $10-20 \%$. Their fruit and vegetable ingestion was extremely low and their sources of vitamins and minerals seemed to be mainly nutritional supplements. The combination of high protein, low fiber and high vitamin ingestion seems to be common among bodybuilders, and has been previously linked to health problems, especially in the gastrointestinal system. ${ }^{5}$ It is important to note that the literature recommends the ingestion of 1.2 to $2 \mathrm{~g}$ of protein per $\mathrm{kg}$ of body weight for strength athletes ${ }^{86-88}$ and there seems to be no benefit in increasing ingestion above this level. ${ }^{82}$ Moreover, previous studies suggested that the maximum amount of protein needed to increase muscle anabolism is around $0.25 \mathrm{~g} / \mathrm{kg},{ }^{89,90}$ which is less than the actual amount ingested by the participants. This extra amount of protein is probably oxidized or eliminated by urea, as suggested by Witard et al. ${ }^{90}$ Recent research shows that a higher protein intake (1.8 vs. $0.85 \mathrm{~g} / \mathrm{kg}$ ) seems to add no benefit in novice athletes. ${ }^{91}$ Therefore, the practice of increased protein intake, also popular in commercial gyms, ${ }^{92,93}$ is not substantiated by the current literature. During the cutting phase, participants increased their protein intake, as previously reported ${ }^{1,2,94}$ The benefits of high-protein diets on weight loss have been highlighted by Leidy et al. ${ }^{95}$ Phillips \& Van Loon ${ }^{71}$ recommended increasing protein intake to 1.8 to $2.7 \mathrm{~g} / \mathrm{kg}$ in order to optimize the ratio of fat-to-lean tissue mass loss during hypoenergetic periods. Additionally, Helms et al. ${ }^{96}$ suggested that 2.3-3.1 g/kg FFM is appropriate for lean, resistance-trained athletes in hypoenergetic conditions. However, it is important to note that, among the studies used to support high-protein diets in the mentioned reviews, only two used protein intakes over $2 \mathrm{~g} / \mathrm{kg}^{97,98}$ and only one compared the effects of different protein intakes. ${ }^{98}$ However, in this study the low protein group ingested only $1 \mathrm{~g} / \mathrm{kg}$ of protein, which is below the recommended values. The results of meta-analyses indicate that the quantity of protein necessary to promote weight management and preserve lean mass lies somewhere between 1.2 and $1.6 \mathrm{~g} / \mathrm{kg} .{ }^{99-101}$ Therefore, it is important that people involved with bodybuilding become aware that high protein intakes are not obligatory to preserve lean mass while losing fat. This can be particularly valuable for people who do not tolerate severe restrictions in carbohydrate or fat.

\section{Nutritional supplements}

Supplements most frequently used for participants of both sexes were concentrated whey protein, chromium picolinate, omega 3 fatty acids, BCAA, poly-vitamins, glutamine and caffeine. Regarding protein supplementation almost all subjects used whey protein. This is not a surprise considering that the most studied type of protein supplementation during resistance training is whey protein in its various forms. On the other hand, the greater part of the data available till now seems to suggest that there is no advantage in assuming whey protein compared to other types of protein. ${ }^{102}$ As suggested by a recent meta-analysis the use of whey protein supplementation concomitant with resistance training results in no benefit when compared to other types of protein. ${ }^{103}$ In general, studies comparing protein from different sources have found no significant differences or conflicting results. Thus, even though body builders seem to prefer whey protein as a protein source for supplementation, there is no convincing data at the moment that could support the hypothesis of a greater muscle mass growth using whey protein over another high-quality source. ${ }^{102}$ The male bodybuilders analyzed, but not the women, also used creatine in the bulking phase. Several studies have suggested a positive effect of creatine supplementation on muscle strength, power and lean body mass. ${ }^{104-106}$ Specifically for bodybuilders, the benefits of creatine may be related to the increased capacity for repeating high intensity efforts, ${ }^{106}$ which can increase training performance and result in muscle size gains. Creatine supplementation has also been associated with increased anabolic signaling ${ }^{107,108}$ reduced myostastin levels, ${ }^{109}$ increased satellite cell activity, augmented myonuclei number ${ }^{110}$ and increased IGF mRNA ${ }^{111}$ which can be related to greater increases in muscle size as compared to placebo. ${ }^{107,112}$ However, creatine supplementation is associated with body water retention, ${ }^{113}$ which may be counterproductive during the cutting phase. This explains why the bodybuilders suspended its use in the weeks before competition and why it was not used by the women. Caffeine was used in order to increase fat loss, due to its supposedly thermogenic effect. However, previous studies reported that caffeine alone offers no benefits over a placebo in thermogenesis ${ }^{114,115}$ and fat loss. ${ }^{116,117}$ The only evidence for a positive effect of 


\section{Strategies adopted by six bodybuilders: a case report}

Eur J Transl Myol 27 (1): 51-66

caffeine on body composition seems to be when combined with ephedrine. Ephedrine's thermogenic effects are probably mediated by an increase in intracellular concentrations of cAMP. However, cAMP is broken down by the enzyme phosphodiesterase, and there is also some evidence that adenosine released from the cells in response to sympathetic stimulation can inhibit the release of beta-receptor agonists and/or act on specific receptors to inhibit the accumulation of cAMP. ${ }^{118}$ Methylxanthines, in particular caffeine, have the ability to inhibit both the effects of adenosine and phosphodiesterase resulting in an increased thermogenic effect when caffeine is combined with ephedrine as compared to ephedrine alone. ${ }^{116-118}$ On the other hand, previous studies suggested that the concomitant ingestion of caffeine and creatine may counteract the beneficial effects of creatine in muscle performance. ${ }^{119,120}$ Therefore, due to the poor evidence for a positive effect of caffeine on body composition and the negative interaction with creatine, as well as the side effects associated with caffeine abuse, ${ }^{121}$ bodybuilders should be conscious about its use, particularly because its effect seems to be relevant only when combined with ephedrine, which is also potentially hazardous to health. Although chromium picolinate was used with the purpose to induce fat loss and decrease carbohydrate craving, previous studies found no benefits of chromium picolinate supplementation in inducing fat $\operatorname{loss}^{108,122,123}$ and appetite control. ${ }^{123}$ However, a previous study suggested that chromium picolinate was beneficial in a subpopulation of patients with high carbohydrate craving, suggesting it may be beneficial for patients with atypical depression who also have severe carbohydrate craving, ${ }^{124}$ which may be the case in some bodybuilders. It is important to note that the safe dose of chromium was not established and the amount used by the participants was significantly above the recommended upper limit, which could have a negative health impact. ${ }^{108,122,123}$ BCAA are commonly used to increase muscle anabolism, increase recovery and prevent catabolism. Previous studies have shown that BCAA may improve anabolic profile after resistance training when compared to a placebo, ${ }^{125,126}$ however, its effects were only seen when BCAA intake was compared to fasting. Considering that the participants already had high protein ingestion coming from animal sources and whey protein supplementation, BCAA would hardly bring any benefit for bodybuilders, as shown in previous studies evaluating anabolic signaling ${ }^{127,128}$ and changes in fat free mass in response to resistance training. ${ }^{129}$ Moreover, its effect in preserving fat free mass is also questionable. ${ }^{130}$ Glutamine, reported to be used for avoiding catabolism and increasing recovery, is another supplement of questionable applicability in bodybuilding. A previous study reported no advantages in muscle performance, body composition or protein degradation when glutamine was combined with resistance training, ${ }^{131}$ and a recent review concluded that glutamine was associated with an improvement in the perception of muscle weakness, but did not improve muscle strength recovery. ${ }^{132}$ Bodybuilders reported using omega 3 fatty acids for cardiovascular protection. Although there is evidence that ingestion of food rich in omega 3 may bring health benefits, the evidence for its supplementation is controversial. ${ }^{133-135}$ However, considering that there is no evidence for adverse events associated with omega 3 supplementation and that the participants' diets were poor in omega 3, supplementation may be warranted.

\section{Overall analysis}

It is important to highlight the body composition results obtained in the present study. Although the competitors used large amounts of anabolic steroids and nutritional supplements in order to improve body composition during all the periods analyzed, their fat-free mass did not change substantially from the beginning to the end of the study. Even in the presence of supraphysiological doses of testosterone, most of them lost fat-free mass during the cutting phase, which suggests a state of overtraining and/or undernutrition derived from mistakes in training, nutrition and/or recovery.

Bodybuilders seem to risk their health in order to increase fat-free mass and then risk their health again to lose fat, but end up losing most of the fat-free mass previously acquired. Maybe it would be more reasonable to gain smaller amounts of muscle mass while minimizing fat gain and then adopt strategies to lose body fat while preserving lean mass. This would virtually extinguish the traditional bulking and cutting phases and promote less aggressive variations in body composition, in addition to decreasing reliance on anabolic steroids and stimulants. The analysis of bodybuilding practices in light of the scientific body of evidence allowed us to find many practices that could negatively impact bodybuilders' health and/or have no potential benefits. With regard to joint problems, the combination of high volumes of upper limb exercises with anabolic steroid abuse may predispose bodybuilders to tendon ruptures. As for cardiovascular risks, the combination of anabolic steroids and stimulants is particularly alarming, since both are independently associated with serious cardiovascular events. In the case of the women, the massive doses of anabolic steroids were surprising. The bodybuilders analyzed relied on a monotonous diet, poor in fiber, vitamins and minerals, associated with the massive use of supplements that have no potential benefits, which may result in health problems and elevated costs. Based on these findings, we recommend the adoption of an evidence-based approach by bodybuilders with a more balanced and less artificial diet. With regard to training, special focus should be given to decreasing training volume, revisiting exercise choice and avoiding fasted 


\section{Strategies adopted by six bodybuilders: a case report}

Eur J Transl Myol 27 (1): 51-66

cardio in order to decrease the reliance on drugs and thus preserve bodybuilders' health and integrity.

The present study has some important limitations. The small number of subjects does not allow generalization, so we cannot confirm if the procedures described here are adopted by the majority of bodybuilders. However, due to the experience of the researchers as coaches and/or athletes along with the reports of the participants, we have strong empirical evidence to believe that many competitors, as well as the general public that take bodybuilders as models, adopt many of the procedures described here. We opted to analyze a small number of subjects in order to gain more detail and retrieve reliable data. Another limitation is that, because of the retrospective characteristic of the study, we were not able to ask for complementary exams or perform specific assessments that would help to clarify many issues, especially regarding health risks. Finally, it is undeniable that the practices adopted by the participants of the study were somehow successful, as they were well ranked in their categories. This apparent success may lead to the fallacy known as "cum hoc ergo propter hoc", and attribute their success to some of their practices. However, there are many intervenient factors, such as drug abuse and genetics, that have to be considered and, more importantly, one must question if their results could have been better if adopting alternative practices. The question that remains is: would they have better results if they adopted a scientific-based approach? Or would they have the same results, but with fewer health risks? Answering these questions is beyond the scope of this study; however, based on a critical analysis and the available literature, we suggest that many practices described here should be avoided or even abolished. Future research aiming to test the use of evidence-based alternatives in bodybuilding preparation is granted.

\section{Author's contributions}

each author contributed in equal part to the manuscript.

\section{Acknowledgments}

We would like to thank all the participants of the study and their coaches for consenting to provide the data.

\section{Conflict of Interest}

The authors submit no conflict of interest regarding the publication of this article.

\section{Corresponding Author}

Paulo Gentil, Faculdade de Educação Física e Dança, Universidade Federal de Goiás - Avenida Esperança s/n, Campus Samambaia - Goiânia, 74690-900, Brazil.

Phone: +59 6235211085 .

E-mail: paulogentil@hotmail.com

\section{E-mails of coAuthors}

Claudio Andre Barbosa de Lira: andre.claudio@gmail.com
Antonio Paoli: antonio.paoli@unipd.it

José Alexandre Barbosa dos Santos:

xandre2.0@hotmail.com

Roberto Deivide Teixeira da Silva:

roberto_silvabm@hotmail.com

José Romulo Pereira Junior:

educadorfisico_2010@yahoo.com.br

Edson Pereira da Silva: mister_edi@hotmail.com

Rodrigo Ferro Magosso: rmagosso@ hotmail.com

\section{References}

1. Walberg-Rankin J. A review of nutritional practices and needs of bodybuilders. J Strength and Cond Res 1995;9:116-124.

2. Newton LE, Hunter G, Bammon M, et al. Changes in psycological state and self-reported diet during various phases of training in competitve bodybuilders. J Strength and Cond Res 1993;7:153-158.

3. Hackett DA, Johnson NA, Chow CM. Training practices and ergogenic aids used by male bodybuilders. J Strength Cond Res 2013;27:160917.

4. Gentil P. A nutrition and conditioning intervention for natural bodybuilding contest preparation: observations and suggestions. J Int Soc Sports Nutr 2015;12:50.

5. Della Guardia L, Cavallaro M, Cena H. The risks of self-made diets: the case of an amateur bodybuilder. J Int Soc Sports Nutr 2015;12:16.

6. Christou GA, Christou KA, Nikas DN, et al. Acute myocardial infarction in a young bodybuilder taking anabolic androgenic steroids: A case report and critical review of the literature. Eur J Prev Cardiol 2016.

7. Siewe J, Marx G, Knoll P, et al. Injuries and overuse syndromes in competitive and elite bodybuilding. Int J Sports Med 2014;35:943-8.

8. Solbach P, Potthoff A, Raatschen HJ, et al. Testosterone-receptor positive hepatocellular carcinoma in a 29-year old bodybuilder with a history of anabolic androgenic steroid abuse: a case report. BMC Gastroenterol 2015;15:60.

9. Ammatuna E, Nijziel MR. Polycythemia and renal infarction in a bodybuilder. QJM 2014;107:661-2.

10. Liborio AB, Nasserala JC, Gondim AS, et al. The case: renal failure in a bodybuilder athlete. Diagnosis: Nephrocalcinosis secondary to exogenous vitamin D intoxication. Kidney Int 2014;85:1247-8.

11. Rivarola MA, Saez JM, Meyer WJ, et al. Metabolic clearance rate and blood production rate of testosterone and androst-4-ene-3,17-dione under basal conditions, ACTH and HCG stimulation. Comparison with urinary production rate of 


\section{Strategies adopted by six bodybuilders: a case report}

Eur J Transl Myol 27 (1): 51-66

testosterone. J Clin Endocrinol Metab 1966;26:1208-18.

12. Kley HK, Niederau C, Stremmel W, et al. Conversion of androgens to estrogens in idiopathic hemochromatosis: comparison with alcoholic liver cirrhosis. J Clin Endocrinol Metab 1985;61:1-6.

13. Meikle AW, Stringham JD, Bishop DT, et al. Quantitating genetic and nongenetic factors influencing androgen production and clearance rates in men. J Clin Endocrinol Metab 1988;67:104-9.

14. Vierhapper $\mathrm{H}$, Nowotny $\mathrm{P}$, Waldhausl W. Determination of testosterone production rates in men and women using stable isotope/dilution and mass spectrometry. J Clin Endocrinol Metab 1997;82:1492-6.

15. Samojlik E, Kirschner MA, Silber D, et al. Elevated production and metabolic clearance rates of androgens in morbidly obese women. J Clin Endocrinol Metab 1984;59:949-54.

16. Perry PJ, Lund BC, Deninger MJ, et al. Anabolic steroid use in weightlifters and bodybuilders: an internet survey of drug utilization. Clin J Sport Med 2005;15:326-30.

17. Kvorning $\mathrm{T}$, Andersen $\mathrm{M}$, Brixen $\mathrm{K}$, et al. Suppression of endogenous testosterone production attenuates the response to strength training: a randomized, placebo-controlled, and blinded intervention study. Am J Physiol Endocrinol Metab 2006;291:E1325-32.

18. Kvorning $\mathrm{T}$, Andersen $\mathrm{M}$, Brixen $\mathrm{K}$, et al. Suppression of testosterone does not blunt mRNA expression of myoD, myogenin, IGF, myostatin or androgen receptor post strength training in humans. J Physiol 2007;578:579-93.

19. Bhasin S, Travison TG, Storer TW, et al. Effect of testosterone supplementation with and without a dual 5alpha-reductase inhibitor on fat-free mass in men with suppressed testosterone production: a randomized controlled trial. Jama 2012;307:931-9.

20. Hartgens F, Kuipers H. Effects of androgenicanabolic steroids in athletes. Sports Med 2004;34:513-54.

21. Hartgens F, Van Marken Lichtenbelt WD, Ebbing $\mathrm{S}$, et al. Androgenic-anabolic steroid-induced body changes in strength athletes. Phys Sportsmed 2001;29:49-65.

22. Hoffman JR, Ratamess NA. Medical issues associated with anabolic steroid use: are they exaggerated? J Sports Sci Med 2006;5:182-93.

23. Hartgens F, Van Marken Lichtenbelt WD, Ebbing $\mathrm{S}$, et al. Body composition and anthropometry in bodybuilders: regional changes due to nandrolone decanoate administration. Int $\mathrm{J}$ Sports Med 2001;22:235-41.

24. Ward P. The effect of an anabolic steroid on strength and lean body mass. Med Sci Sports 1973;5:277-82.
25. Lovejoy JC, Bray GA, Bourgeois MO, et al. Exogenous androgens influence body composition and regional body fat distribution in obese postmenopausal women--a clinical research center study. J Clin Endocrinol Metab 1996;81:2198-203.

26. Supasyndh O, Satirapoj B, Aramwit P, et al. Effect of oral anabolic steroid on muscle strength and muscle growth in hemodialysis patients. Clin J Am Soc Nephrol 2013;8:271-9.

27. Halstead LS, Groah SL, Libin A, et al. The effects of an anabolic agent on body composition and pulmonary function in tetraplegia: a pilot study. Spinal Cord 2010;48:55-9.

28. Abrams D. Use of androgens in patients who have HIV/AIDS: what we know about the effect of androgens on wasting and lipodystrophy. AIDS Read 2001;11:149-56.

29. O'Reilly MW, House PJ, Tomlinson JW. Understanding androgen action in adipose tissue. J Steroid Biochem Mol Biol 2014;143:277-84.

30. Fujioka K, Kajita K, Wu Z, et al. Dehydroepiandrosterone reduces preadipocyte proliferation via androgen receptor. Am J Physiol Endocrinol Metab 2012;302:E694-704.

31. Semirale AA, Zhang XW, Wiren KM. Body composition changes and inhibition of fat development in vivo implicates androgen in regulation of stem cell lineage allocation. J Cell Biochem 2011;112:1773-86.

32. Juang PS, Peng S, Allehmazedeh $\mathrm{K}$, et al. Testosterone with dutasteride, but not anastrazole, improves insulin sensitivity in young obese men: a randomized controlled trial. J Sex Med 2014;11:563-73.

33. Chobanian AV, Bakris GL, Black HR, et al. Seventh report of the Joint National Committee on Prevention, Detection, Evaluation, and Treatment of High Blood Pressure. Hypertension 2003;42:1206-52.

34. Vanberg P, Atar D. Androgenic anabolic steroid abuse and the cardiovascular system. Handb Exp Pharmacol 2010:411-57.

35. Sonmez E, Turkdogan KA, Yilmaz C, et al. Chronic anabolic androgenic steroid usage associated with acute coronary syndrome in bodybuilder. Turk J Emerg Med 2016;16:35-7.

36. Frati P, Busardo FP, Cipolloni L, et al. Anabolic Androgenic Steroid (AAS) related deaths: autoptic, histopathological and toxicological findings. Curr Neuropharmacol 2015;13:146-59.

37. Wysoczanski M, Rachko M, Bergmann SR. Acute myocardial infarction in a young man using anabolic steroids. Angiology 2008;59:376-8.

38. Montisci R, Cecchetto G, Ruscazio M, et al. Early Myocardial Dysfunction After Chronic Use of Anabolic Androgenic Steroids: Combined PulsedWave Tissue Doppler Imaging and Ultrasonic Integrated Backscatter Cyclic Variations Analysis. 


\section{Strategies adopted by six bodybuilders: a case report}

Eur J Transl Myol 27 (1): 51-66

Journal of the American Society of Echocardiography 2010;23:516-522.

39. Rogol AD, Yesalis CE, 3rd. Clinical review 31: Anabolic-androgenic steroids and athletes: what are the issues? J Clin Endocrinol Metab 1992;74:465-9.

40. Kutscher EC, Lund BC, Perry PJ. Anabolic steroids: a review for the clinician. Sports Med 2002;32:285-96.

41. Kicman AT. Pharmacology of anabolic steroids. Br J Pharmacol 2008;154:502-21.

42. Angell P, Chester N, Green D, et al. Anabolic steroids and cardiovascular risk. Sports Med 2012;42:119-34.

43. Haller CA, Benowitz NL. Adverse cardiovascular and central nervous system events associated with dietary supplements containing ephedra alkaloids. N Engl J Med 2000;343:1833-8.

44. Andraws R, Chawla P, Brown DL. Cardiovascular effects of ephedra alkaloids: a comprehensive review. Prog Cardiovasc Dis 2005;47:217-25.

45. Cadwallader AB, de la Torre X, Tieri A, et al. The abuse of diuretics as performance-enhancing drugs and masking agents in sport doping: pharmacology, toxicology and analysis. British journal of pharmacology 2010;161:1-16.

46. Price AL, Lingvay I, Szczepaniak EW, et al. The metabolic cost of lowering blood pressure with hydrochlorothiazide. Diabetol Metab Syndr 2013;5:35

47. Haussinger D, Roth E, Lang F, et al. Cellular hydration state: an important determinant of protein catabolism in health and disease. Lancet 1993;341:1330-2.

48. Berneis K, Ninnis R, Haussinger D, et al. Effects of hyper- and hypoosmolality on whole body protein and glucose kinetics in humans. Am J Physiol 1999;276:E188-95.

49. Keller U, Szinnai G, Bilz S, et al. Effects of changes in hydration on protein, glucose and lipid metabolism in man: impact on health. Eur J Clin Nutr 2003;57 Suppl 2:S69-74.

50. Schoenfeld BJ, Ogborn D, Krieger JW. Doseresponse relationship between weekly resistance training volume and increases in muscle mass: A systematic review and meta-analysis. J Sports Sci 2016:1-10.

51. Ostrowski KJ, Wilson GJ, Weatherby R, et al. The effect of weight training volume on hormonal output and muscular size and function. J Strength and Cond Res 1997;11:148-154.

52. Ahtiainen JP, Lehti M, Hulmi JJ, et al. Recovery after heavy resistance exercise and skeletal muscle androgen receptor and insulin-like growth factor-I isoform expression in strength trained men. J Strength Cond Res 2011;25:767-77.
53. McCaw ST, Friday JJ. A comparison of muscle activity between a free weight and machine bench press. J Strength and Cond Res 1994;8:259-264.

54. Clemons JM, Aaron C. Effect of grip width on the myoelectric activity of the prime movers in the bench press. J Strength and Cond Res 1997;11:82.

55. Sperandei S, Barros MA, Silveira-Junior PC, et al. Electromyographic analysis of three different types of lat pull-down. J Strength Cond Res 2009;23:2033-8.

56. Rocha Jr VA, Gentil P, Oliveira E, et al. Comparação entre a atividade EMG do peitoral maior, deltóide anterior e tríceps braquial durante os exercícios supino reto e crucifixo. Rev Bras Med Esporte 2007;13:51-54.

57. Gentil P, Soares S, Bottaro M. Single vs. MultiJoint Resistance Exercises: Effects on Muscle Strength and Hypertrophy. Asian J Sports Med 2015;6:e24057.

58. Gentil P, Soares SR, Pereira MC, et al. Effect of adding single-joint exercises to a multi-joint exercise resistance-training program on strength and hypertrophy in untrained subjects. Appl Physiol Nutr Metab 2013;38:341-4.

59. de Franca HS, Branco PA, Guedes Junior DP, et al. The effects of adding single-joint exercises to a multi-joint exercise resistance training program on upper body muscle strength and size in trained men. Appl Physiol Nutr Metab 2015;40:822-6.

60. Soares S, Ferreira-Junior JB, Pereira MC, et al. Dissociated Time Course of Muscle Damage Recovery Between Single- and Multi-Joint Exercises in Highly Resistance-Trained Men. J Strength Cond Res 2015;29:2594-2599.

61. Lehman GJ, Buchan DD, Lundy A, et al. Variations in muscle activation levels during traditional latissimus dorsi weight training exercises: An experimental study. Dyn Med 2004;3:4.

62. Serra C, Tangherlini F, Rudy S, et al. Testosterone improves the regeneration of old and young mouse skeletal muscle. J Gerontol A Biol Sci Med Sci 2013;68:17-26.

63. Wolfe R, Ferrando A, Sheffield-Moore M, et al. Testosterone and muscle protein metabolism. Mayo Clin Proc 2000;75 Suppl:S55-9; discussion S59-60.

64. Kvorning T, Kadi F, Schjerling P, et al. The activity of satellite cells and myonuclei following 8 weeks of strength training in young men with suppressed testosterone levels. Acta Physiol (Oxf) 2015;213:676-87.

65. Allouh MZ, Aldirawi MH. Effects of sustanon on the distribution of satellite cells and the morphology of skeletal muscle fibers during maturation. Pak J Biol Sci 2012;15:215-23.

66. Seynnes OR, Kamandulis S, Kairaitis R, et al. Effect of androgenic-anabolic steroids and heavy 


\section{Strategies adopted by six bodybuilders: a case report}

Eur J Transl Myol 27 (1): 51-66

strength training on patellar tendon morphological and mechanical properties. J Appl Physiol (1985) 2013;115:84-9.

67. Kanayama G, DeLuca J, Meehan WP, 3rd, et al. Ruptured Tendons in Anabolic-Androgenic Steroid Users: A Cross-Sectional Cohort Study. Am J Sports Med 2015;43:2638-44.

68. Paoli A, Moro T, Marcolin G, et al. High-Intensity Interval Resistance Training (HIRT) influences resting energy expenditure and respiratory ratio in non-dieting individuals. Journal of translational medicine 2012;10:237.

69. Paoli A, Pacelli QF, Moro T, et al. Effects of highintensity circuit training, low-intensity circuit training and endurance training on blood pressure and lipoproteins in middle-aged overweight men. Lipids in Health and Disease 2013;12:131.

70. Paoli A, Pacelli F, Bargossi AM, et al. Effects of three distinct protocols of fitness training on body composition, strength and blood lactate. The Journal of sports medicine and physical fitness 2010;50:43-51.

71. Phillips SM, Van Loon LJ. Dietary protein for athletes: from requirements to optimum adaptation. J Sports Sci 2011;29 Suppl 1:S29-38.

72. Kraemer WJ, Marchitelli L, Gordon SE, et al. Hormonal and growth factor responses to heavy resistance exercise protocols. Journal of applied physiology (Bethesda, Md.: 1985) 1990;69:14421450.

73. Bottaro M, Martins B, Gentil P, et al. Effects of rest duration between sets of resistance training on acute hormonal responses in trained women. Journal of science and medicine in sport / Sports Medicine Australia 2009;12:73-78.

74. Yasuda T, Fukumura K, Fukuda T, et al. Muscle size and arterial stiffness after blood flowrestricted low-intensity resistance training in older adults. Scand J Med Sci Sports 2014;24:799-806.

75. Ireland ML, Willson JD, Ballantyne BT, et al. Hip strength in females with and without patellofemoral pain. J Orthop Sports Phys Ther 2003;33:671-6.

76. Magalhaes E, Fukuda TY, Sacramento SN, et al. A comparison of hip strength between sedentary females with and without patellofemoral pain syndrome. J Orthop Sports Phys Ther 2010;40:641-7.

77. Fukuda TY, Melo WP, Zaffalon BM, et al. Hip posterolateral musculature strengthening in sedentary women with patellofemoral pain syndrome: a randomized controlled clinical trial with 1-year follow-up. J Orthop Sports Phys Ther 2012;42:823-30.

78. Fukuda TY, Rossetto FM, Magalhaes E, et al. Short-term effects of hip abductors and lateral rotators strengthening in females with patellofemoral pain syndrome: a randomized controlled clinical trial. J Orthop Sports Phys Ther 2010;40:736-42.

79. Schoenfeld BJ, Aragon AA, Wilborn CD, et al. Body composition changes associated with fasted versus non-fasted aerobic exercise. J Int Soc Sports Nutr 2014;11:54.

80. Paoli A, Marcolin G, Zonin F, et al. Exercising fasting or fed to enhance fat loss? Influence of food intake on respiratory ratio and excess postexercise oxygen consumption after a bout of endurance training. International Journal of Sport Nutrition and Exercise Metabolism 2011;21:48-54.

81. Magkos F, Kavouras SA. Caffeine and ephedrine: physiological, metabolic and performanceenhancing effects. Sports Med 2004;34:871-89.

82. Graham TE. Caffeine, coffee and ephedrine: impact on exercise performance and metabolism. Can J Appl Physiol 2001;26 Suppl:S103-19.

83. Wilson JM, Loenneke JP, Jo E, et al. The effects of endurance, strength, and power training on muscle fiber type shifting. J Strength Cond Res 2012;26:1724-9.

84. Del Vecchio FB, Gentil P, Coswig VS, et al. Commentary: Why sprint interval training is inappropriate for a largely sedentary population. Front Psychol 2015;6:1359.

85. Boutcher SH. High-intensity intermittent exercise and fat loss. Journal of obesity 2011;2011:868305.

86. Lemon PW, Tarnopolsky MA, MacDougall JD, et al. Protein requirements and muscle mass/strength changes during intensive training in novice bodybuilders. Journal of applied physiology (Bethesda, Md.: 1985) 1992;73:767-775.

87. Lemon PW. Protein and amino acid needs of the strength athlete. Int J Sport Nutr 1991;1:127-45.

88. Campbell B, Kreider RB, Ziegenfuss T, et al. International Society of Sports Nutrition position stand: protein and exercise. Journal of the International Society of Sports Nutrition 2007;4:8.

89. West DWD, Kujbida GW, Moore DR, et al. Resistance exercise-induced increases in putative anabolic hormones do not enhance muscle protein synthesis or intracellular signalling in young men. J Physiol 2009;587:5239-5247.

90. Witard OC, Jackman SR, Breen L, et al. Myofibrillar muscle protein synthesis rates subsequent to a meal in response to increasing doses of whey protein at rest and after resistance exercise. Am J Clin Nutr 2014;99:86-95.

91. Paoli A, Pacelli QF, Cancellara P, et al. Protein Supplementation Does Not Further Increase Latissimus Dorsi Muscle Fiber Hypertrophy after Eight Weeks of Resistance Training in Novice Subjects, but Partially Counteracts the Fast-toSlow Muscle Fiber Transition. Nutrients 2016;8.

92. Bianco A, Mammina C, Thomas E, et al. Protein supplementation and dietary behaviours of resistance trained men and women attending 


\section{Strategies adopted by six bodybuilders: a case report}

Eur J Transl Myol 27 (1): 51-66

commercial gyms: a comparative study between the city centre and the suburbs of Palermo, Italy. Journal of the International Society of Sports Nutrition 2014;11.

93. Bianco A, Mammina C, Paoli A, et al. Protein supplementation in strength and conditioning adepts: knowledge, dietary behavior and practice in Palermo, Italy. Journal of the International Society of Sports Nutrition 2011;8.

94. Robinson SL, Lambeth-Mansell A, Gillibrand G, et al. A nutrition and conditioning intervention for natural bodybuilding contest preparation: case study. J Int Soc Sports Nutr 2015;12:20.

95. Leidy HJ, Clifton PM, Astrup A, et al. The role of protein in weight loss and maintenance. Am J Clin Nutr 2015.

96. Helms ER, Zinn C, Rowlands DS, et al. A systematic review of dietary protein during caloric restriction in resistance trained lean athletes: a case for higher intakes. Int J Sport Nutr Exerc Metab 2014;24:127-38.

97. Maestu J, Eliakim A, Jurimae J, et al. Anabolic and catabolic hormones and energy balance of the male bodybuilders during the preparation for the competition. J Strength Cond Res 2010;24:107481.

98. Mettler S, Mitchell N, Tipton KD. Increased protein intake reduces lean body mass loss during weight loss in athletes. Med Sci Sports Exerc 2010;42:326-37.

99. Leidy HJ, Carnell NS, Mattes RD, et al. Higher protein intake preserves lean mass and satiety with weight loss in pre-obese and obese women. Obesity (Silver Spring) 2007;15:421-9.

100. Soenen S, Martens EA, Hochstenbach-Waelen A, et al. Normal protein intake is required for body weight loss and weight maintenance, and elevated protein intake for additional preservation of resting energy expenditure and fat free mass. J Nutr 2013;143:591-6.

101. Layman DK, Evans E, Baum JI, et al. Dietary protein and exercise have additive effects on body composition during weight loss in adult women. J Nutr 2005;135:1903-10.

102. Reidy PT, Rasmussen BB. Role of Ingested Amino Acids and Protein in the Promotion of Resistance Exercise-Induced Muscle Protein Anabolism. J Nutr 2016;146:155-83.

103. Miller PE, Alexander DD, Perez V. Effects of whey protein and resistance exercise on body composition: a meta-analysis of randomized controlled trials. J Am Coll Nutr 2014;33:163-75.

104. Gualano B, Roschel H, Lancha-Jr AH, et al. In sickness and in health: the widespread application of creatine supplementation. Amino Acids 2012;43:519-29.

105. Gualano B, Rawson ES, Candow DG, et al. Creatine supplementation in the aging population: effects on skeletal muscle, bone and brain. Amino Acids 2016.

106. Lanhers C, Pereira B, Naughton G, et al. Creatine Supplementation and Upper Limb Strength Performance: A Systematic Review and MetaAnalysis. Sports Med 2016.

107. Willoughby DS, Rosene J. Effects of oral creatine and resistance training on myosin heavy chain expression. Med Sci Sports Exerc 2001;33:167481.

108. Willoughby DS, Rosene JM. Effects of oral creatine and resistance training on myogenic regulatory factor expression. Med Sci Sports Exerc 2003;35:923-9.

109. Saremi A, Gharakhanloo R, Sharghi S, et al. Effects of oral creatine and resistance training on serum myostatin and GASP-1. Mol Cell Endocrinol 2010;317:25-30.

110. Olsen S, Aagaard P, Kadi F, et al. Creatine supplementation augments the increase in satellite cell and myonuclei number in human skeletal muscle induced by strength training. J Physiol 2006;573:525-34.

111. Deldicque L, Louis M, Theisen D, et al. Increased IGF mRNA in human skeletal muscle after creatine supplementation. Med Sci Sports Exerc 2005;37:731-6.

112. Chilibeck PD, Stride D, Farthing JP, et al. Effect of creatine ingestion after exercise on muscle thickness in males and females. Med Sci Sports Exerc 2004;36:1781-8.

113. Powers ME, Arnold BL, Weltman AL, et al. Creatine Supplementation Increases Total Body Water Without Altering Fluid Distribution. J Athl Train 2003;38:44-50.

114. Falk B, Burstein R, Rosenblum J, et al. Effects of caffeine ingestion on body fluid balance and thermoregulation during exercise. Can J Physiol Pharmacol 1990;68:889-92.

115. Haller CA, Jacob P, 3rd, Benowitz NL. Enhanced stimulant and metabolic effects of combined ephedrine and caffeine. Clin Pharmacol Ther 2004;75:259-73.

116. Astrup A, Breum L, Toubro S, et al. The effect and safety of an ephedrine/caffeine compound compared to ephedrine, caffeine and placebo in obese subjects on an energy restricted diet. A double blind trial. Int J Obes Relat Metab Disord 1992;16:269-77.

117. Astrup A, Toubro S, Christensen NJ, et al. Pharmacology of thermogenic drugs. Am J Clin Nutr 1992;55:246S-248S.

118. Dulloo AG, Miller DS. The thermogenic properties of ephedrine/methylxanthine mixtures: animal studies. Am J Clin Nutr 1986;43:388-94.

119. Hespel P, Op't Eijnde B, Van Leemputte M. Opposite actions of caffeine and creatine on 


\section{Strategies adopted by six bodybuilders: a case report}

Eur J Transl Myol 27 (1): 51-66

muscle relaxation time in humans. J Appl Physiol (1985) 2002;92:513-8.

120. Vandenberghe K, Gillis N, Van Leemputte M, et al. Caffeine counteracts the ergogenic action of muscle creatine loading. J Appl Physiol 1996;80:452-7.

121. Pallares JG, Fernandez-Elias VE, Ortega JF, et al. Neuromuscular responses to incremental caffeine doses: performance and side effects. Med Sci Sports Exerc 2013;45:2184-92.

122. Vincent JB. The potential value and toxicity of chromium picolinate as a nutritional supplement, weight loss agent and muscle development agent. Sports Med 2003;33:213-30.

123. Golubnitschaja O, Yeghiazaryan K. Opinion controversy to chromium picolinate therapy's safety and efficacy: ignoring 'anecdotes' of case reports or recognising individual risks and new guidelines urgency to introduce innovation by predictive diagnostics? EPMA J 2012;3:11.

124. Docherty JP, Sack DA, Roffman M, et al. A double-blind, placebo-controlled, exploratory trial of chromium picolinate in atypical depression: effect on carbohydrate craving. J Psychiatr Pract 2005;11:302-14.

125. Borgenvik M, Apro W, Blomstrand E. Intake of branched-chain amino acids influences the levels of MAFbx mRNA and MuRF-1 total protein in resting and exercising human muscle. Am J Physiol Endocrinol Metab 2012;302:E510-21.

126. Karlsson HK, Nilsson PA, Nilsson $J$, et al. Branched-chain amino acids increase p70S6k phosphorylation in human skeletal muscle after resistance exercise. Am J Physiol Endocrinol Metab 2004;287:E1-7.

127. Ferreira MP, Li R, Cooke M, et al. Periexercise coingestion of branched-chain amino acids and carbohydrate in men does not preferentially augment resistance exercise-induced increases in phosphatidylinositol 3 kinase/protein kinase Bmammalian target of rapamycin pathway markers indicative of muscle protein synthesis. Nutr Res 2014;34:191-8.

128. Churchward-Venne TA, Breen L, Di Donato DM, et al. Leucine supplementation of a low-protein mixed macronutrient beverage enhances myofibrillar protein synthesis in young men: a double-blind, randomized trial. Am J Clin Nutr 2014;99:276-86.

129. Spillane M, Emerson C, Willoughby DS. The effects of 8 weeks of heavy resistance training and branched-chain amino acid supplementation on body composition and muscle performance. Nutr Health 2012;21:263-73.

130. Dieter BP, Schoenfeld BJ, Aragon AA. The data do not seem to support a benefit to BCAA supplementation during periods of caloric restriction. J Int Soc Sports Nutr 2016;13:21.

131. Candow DG, Chilibeck PD, Burke DG, et al. Effect of glutamine supplementation combined with resistance training in young adults. Eur $\mathbf{J}$ Appl Physiol 2001;86:142-9.

132. Hernandez Valencia SE, Mendez Sanchez L, Clark $\mathrm{P}$, et al. [Glutamine as an Aid in the Recovery of Muscle Strength: Systematic Review of Literature]. Nutr Hosp 2015;32:1443-53.

133. Enns JE, Yeganeh A, Zarychanski R, et al. The impact of omega-3 polyunsaturated fatty acid supplementation on the incidence of cardiovascular events and complications in peripheral arterial disease: a systematic review and meta-analysis. BMC Cardiovasc Disord 2014;14:70.

134. Nestel P, Clifton P, Colquhoun D, et al. Indications for Omega-3 Long Chain Polyunsaturated Fatty Acid in the Prevention and Treatment of Cardiovascular Disease. Heart Lung Circ 2015;24:769-79.

135. Maehre HK, Jensen IJ, Elvevoll EO, et al. omega-3 Fatty Acids and Cardiovascular Diseases: Effects, Mechanisms and Dietary Relevance. Int J Mol Sci 2015;16:22636-61. 